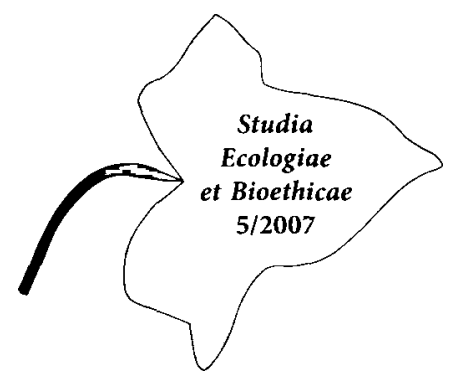

\title{
Wpływ działalności promocyjno-informacyjnej administracji państwowej i samorządowej na rozwój regionu na podstawie badań przeprowadzonych w Ełku
}

\begin{abstract}
Wstęp
Promocja jest jednym z najważniejszych narzędzi w działalności człowieka. Właściwie nie ma dziedziny w której w mniejszym lub większym stopniu nie wykorzystywano by form promocji. Jeśli by spojrzeć na promocję pod kątem historycznym czy antropologicznym to właściwie w swoich pierwotnych formach towarzyszy nam od zarania dziejów, a nawet wpisana jest w naszą naturę. Idąc tym nurtem, za pierwotne formy promocji można uznać autopromocję własnych wdzięków.

Promocja, w jej współczesnym rozumieniu uczestniczy we wszystkich dziedzinach działalności człowieka, począwszy od promocji zdrowia, poprzez różne formy reklamy na marketingu politycznym skończywszy. Mnie najbardziej interesuje promocja jako niezbędne narzędzie w działalności społeczno-gospodarczej.

Polska ma skromne doświadczenia w działalnosci promocyjnej. Uwolnienie rynku na początku lat 90-tych było niezbędnym posunięciem ze strony ówczesnego rządu, które zapoczątkowało proces wdrażania na polski grunt mechanizmów działajacych z powodzeniem w krajach Europy Zachodniej od kilku dziesięcioleci. Wolny rynek wymusza na naszym kraju przyspieszoną naukę metod i strategii działania w obliczu dużej konkurencji. Mimo tego, że od kil$\mathrm{ku}$ lat obserwujemy wielki postęp w dziedzinie promocji, to nadal nie w pełni wykorzystujemy możliwości, jakie daje nam to narzędzie, tak istotne w rozwoju gospodarczym.

Zastosowanie technik promocji bardzo dobrze się sprawdza w turystyce i ochronie środowiska. Dziś właściwie trudno wyobrazic sobie właściwie funkcjonowanie tych dziedzin bez promocji. Mechanizmy promocyjne z powodzeniem stosowane są $w$ rozreklamowaniu ekologicznej turystyki a poszczególnych
\end{abstract}


regionów, miast jako przyjaznych przyrodzie. Jednym z takich regionów w Polsce jest miasto Ełk i jego okolice.

Współczesne miasta często są przedmiotem zainteresowań przedstawicieli różnych dziedzin. Zespoły powołane przez specjalistów rozpatrują różne koncepcje rozwiązania problemów z jakimi borykają się miasta. Często jedyną szansą dla poprawy sytuacji społ-gospodarczej oraz zainicjowaniu rozwoju jest promocja. W Europie można mnożyc przykłady miast w których koncepcja rozwoju oparta o strategie marketingowe przyniosła sukcesy $\mathrm{w}$ postaci znaczącego wzrostu atrakcyjności gospodarczej oraz turystycznej, co bezpośrednio przełożyło się na poprawę warunków życia miaszkańców. Miastem, ktore w ten sposób chce budowac swoja przyszłość jest Ełk.

\section{Ełk-charakterystka miasta i regionu}

Ełk to miasto powiatowe położone w województwie warmińsko-mazurskim spełniające rolę głównego ośrodka miejskiego we wschodniej jego części, położone nad rzeką Ełk i Jeziorem Ełckim. Region stanowi centrum Pojezierza Ełckiego, krainy mazurskiej słynącej z bujnych lasów, licznych jezior - w promieniu $15 \mathrm{~km}$ ponad 100, rzek, strumyków, oraz licznych pagórków, co w całości komponuje się w piękny krajobraz.

Ełk jako największe miasto w tej cześci Mazur spełnia liczne funkcje spoleczno-gospodarcze. Duża odległość od stolicy województwa wymusiła utworzenie zamiejscowych filii najważniejszych urzędów, są to delegatury m.in.: Urzędu Wojewódzkiego, Urzędu Marszałkowskiego, Kuratorium Oświaty, Państwowej Inspekcji Pracy, Państwowej Inspekcji Handlowej oraz Narodowego Funduszu Zdrowia.

Współcześnie miasto zajmuje powierzchnię 2,107 ha i posiada ponad 56 tysięcy miaszkańców. Na terenie Ełku znajdują się 79 szkoły, w skład których wchodzi: 6 szkół podstawowych, 4 gimnazja i zespół szkół prowadzone przez samorząd miejski, 8 zespołów szkół oraz Centrum Kształcenia Praktycznego i Ustawicznego prowadzone przez samorząd powiatowy. Istnieją również szkoły artystyczne oraz specjalne.

W Ełku funkcjonują uczelnie wyższe, na których studiuje ponad 2500 studentów. Są to: Centrum Studiów Bałtyckich Uniwersytetu Warmińsko-Mazurskiego w Olsztynie, Filia Wyższej Szkoły Finansów i Zarządzania w Białymstoku oraz Wyższe Seminarium Duchowne. Studiuje w nich około 2.500 studentów.

Bolączką miasta-powiatu jest bardzo wysokie bezrobocie sięgające aż 30\%. Największymi zakładami przemysłowymi w mieście są słynne z jakości swoich wyrobów zakłady mięsne „Mazury”, założone w 1907 r., obecnie produkujące między innymi na rynek Unii Europejskiej oraz USA. Kolejnymi pod wzgledem 
zatrudnienia osób są znajdujące się w Ełku i okolicach liczne zakłady zajmujace sie przetwórstwem drewna. Na mapie zatrudnienia istotną pozycję zajmuje również Zakład Elektrotechniki Motoryzacyjnej, dawniej będący wytwórnią sprzętu kolejowego.

Miasto Ełk wchodzi w skład Suwalskiej Specjalnej Strefy Ekonomicznej. Obecnie w ełckiej Podstrefie funkcjonuje 25 zakładów łącznie zatrudniających prawie 1,5 tys. osób. Są to głównie firmy $z$ kapitałem polskim, także lokalnym oraz z kapitałem zagranicznym.

Ełk ma bardzo dobre połączenie komunikacyjne z innymi ważnymi osrodkami miejskimi. Przez miasto przebiegają ważne szlaki komunikacji samochodowej oraz kolejowej. Posiada wiele stałych połączeń kolejowych oraz autobusowych m.in z Białymstokiem, Olsztynem, Warszawą, Suwałkami, Łomżą.

Ełk to bardzo ważny ośrodek kulturalny w regionie, na terenie którego działają liczne centra kultury, w skład których wchodzą teatry i zespoły, biblioteki, galerie fotograficzne oraz pracownie. W Ełku można również obejrzeć film w kinie Polonia lub skorzystać z usług Miejskiej Biblioteki Publicznej'. Warto zwiedzić Muzeum Zabytków Kolejnictwa prowadzone przez braci Sawczyńskich, Muzeum „Kropli Wody” w Wieży Ciśnień oraz Muzeum Jeziora w Centrum Edukacji Ekologicznej. Miłośnicy zwierząt i amatorzy jazdy konnej mogą odwiedzić prywatne mini zoo i wybrać się do Ośrodka Jeździeckiego w Ełku lub Stadniny Koni w Stradunach. W Ełku można również znaleźć atrakcje przygotowane specjalnie dla najmłodszych, np. Figloraj - sala zabaw dla dzieci. Przykładem lokalnych ośrodków kultury jest Spółdzielczy Dom Kultury Spółdzielni Mieszkaniowej "Świt”, który od kilku lat organizuje coroczny konkurs fotograficzny pt. „EkoEłk”. Konkurs ewoluował i nabierał rozmachu, by w końcu przerodzić się w Ogólnopolski Konkurs Fotograficzny pt. „Złap oddech Zielonych Płuc Polski”.

Miasto jest bardzo atrakcyjne turystycznie. Mnogość propozycji turystycznych oraz przygotowanych szlaków sprawia,że zarówno mieszkańcy, jak i przyjezdni bardzo chętnie korzystają z tych atrakcji. Szlaki prowadzą po najpiękniejszych okolicach i służą szczególnie tym, dla których aktywna turystyka łączy się z wypoczynkiem i poznawaniem przyrody. Szczególnie warte uwagi są szlaki, zarówno na piesze, jak też rowerowe wycieczki, a zimą narciarskie im. Michała Kajki (37 km, z Ełku do Skomacka Wielkiego), Szlak Tatarski $(19 \mathrm{~km})$ i trasę Mazur Garbatych z Ełku do Gołdapi $(135 \mathrm{~km})$. Rowerem można również pojechać Szlakiem Zielonym do Bogusz (19 km) lub dalej do Grajewa, Rajgrodu, Olecka, Augustowa, Orzysza, Starych Juch, Szarejek lub Woszczel. W Ełku zaczynają się też dwie trasy wodne: do Czerwonego Dworu $(80 \mathrm{~km})$ i szlak kajakowy prowadzący na Jezioro Orzysz $(40 \mathrm{~km})$ i dalej na Wielkie Jeziora Mazurskie.

www.biblioteka.elk.pl

www.smswit.elk.com.pl/kultura.htm 
Ciekawą propozycję turystyczną stanowi również możliwość przejażdżki zabytkową Kolejką Wąskotorową.

$\mathrm{Na}$ terenie miasta i regionu znajduje się rozbudowana baza gastronomiczno-hotelarska. Wzrost zainteresowania regionem wśród turystów z innych krajów Europy wymusił rozbudowę i modernizację już istniejacej bazy. Obecnie nawet najbardziej wybredni turyści będą mieli wybór spośród propozycji. Ełk i okolice cieszą się największym zainteresowaniem w sezonie letnim, co związane jest głównie $z$ atrakcjami wodnymi. W ciągu ostatnich kilku lat zauważalny jest wzrost zainteresowania turystów także poza sezonem letnim. Wielu właścicieli obiektów turystycznych obecnie proponuje swoje usługi przez cały rok. Liczne smażalnie oraz restauracje serwują przysmaki kuchni regionalnej jak dania z ryb smażonych i wędzonych, babka i kiszka ziemniaczana, kartacze.

\section{Rys historyczny miasta Ełk}

Tereny miasta Ełk i okolic we wczesnym średniowieczu wchodziły w skład ziem zajmowanych przez plemię Jaćwingów. Są oni pierwszymi budowniczymi na wyspie na Jeziorze Ełckim. Ich budowla miała charakter obronny. Strategiczne walory tego miejsca w XIVw. dostrzegli licznie występujacy na tych terenach Krzyżacy, którzy wybudowali tam niewielki zamek. Budowla została zburzona w kilka lat po przegranej bitwie pod Grunwaldem.

Najdawniejsze zapiski mówią, że założycielem Ełku i pierwszym sołtysem wsi był Bartosz Bratomil. Bardzo korzystne położenie sprawiało,że Ełk rozwijał się szybko i wkrótce otrzymał prawa miejskie od wielkiego mistrza Pawła von Russdorfa. Data nadania tych praw nie jest jednoznaczna, więc czesto przyjmuje się datę założenia wsi, czyli rok 1425. Intensywne zasiedlania tych terenów po wojnie trzynastoletniej owocowało rozwojem wsi, która w 1499 r. liczyła około 600 osób.

„Okresem największego rozwoju Ełku był XVI w. W 1536 r. do Ełku przybył Jan z Sącza, który przyjął nazwisko Małecki. Wydawał on książki w języku polskim. W 1599 r. istniejąca szkoła w Ełku została szkołą książęcą. W latach 1547-51 odbudowano kościól parafialny pod wezwaniem św. Katarzyny. W tym samym czasie powstał również szpital. Podstawą dalszego rozwoju Ełku był przywilej księcia Albrechta $\mathrm{z}$ roku 1560 ustanawiający targ tygodniowy.

Ełk nawiedzało wiele klęsk: 1625 - zaraza, 1651 - wielki pożar, 1655 - Tatarzy spalili miasto i wymordowali ludność. Podniesienie się Ełku z ruiny utrudnił wielki pożar w 1688 r. Dalsze lata były okresem wzrastającej stagnacji.

W 1800 r. powstało polskie seminarium nauczycielskie, którego organizatorem i kierownikiem był arcyprezbiter ełcki - Tymoteusz Gizewiusz, doskonały znawca języka polskiego. Pierwsza połowa XIX w. przyniosła kolejne tragedie. Pożary spowodowały, że Ełk robi wrażenie miasta XIX wiecznego. Nie ma tu 
żadnego wcześniejszego zabytku. W roku 1868 nastąpiło otwarcie linii kolejowej Ełk - Królewiec. Lata I Wojny światowej przyniosły miastu kolejne klęski. Miasto znalazło się na linii frontu. Trzykrotnie dostawało się w ręce Rosjan. Na skutek bombardowań zniszczone zostało całe śródmieście.

W okresie międzywojennym Ełk przeżył okres rozwoju gospodarczego. $Z$ tego okresu pochodzi jego śródmieście.

Dalszy rozwój przypadł na lata powojenne. Miasto zasiedlone zostało szybko głównie przez przybyszów z niedalekich okolic. Znaczący udział w rozwoju miasta mieli i mają dotychczas, byli mieszkańcy kresów z Grodzieńszczyzny i Wileńszczyzny. W 1992 roku Ełk stał się siedzibą Diecezji. Dzięki temu odzyskał swoją historyczną rolę Duchowej Stolicy Mazur"3.

\section{Działalność promocyjna i informacyjna dla rozwoju miasta Elk i regionu}

Ziemia ełcka to obszar charakteryzujący się nadzwyczajnymi walorami przyrodniczymi, unikatowymi w skali europejskiej. Jest to niewątpiliwy atut regionu bardzo sprzyjający rozwojowi wszelkich form turystyki. Bardzo urozmaicony krajobraz z dużą ilością jezior, kompleksami leśnymi. Bogata gatunkowo fauna i flora, zabytki architektury i techniki sprawiają, że turystyka może i powinna stać się jedną z najważniejszych gałęzi gospodarki regionu.

Współczesne mechanizmy wolnorynkowe wymuszają szereg działań służących prezentacji swojego produktu czy też usługi, to jest miejsce dla różnych form promocji. Turystyka ekologiczna jest usługą, więc nie może być mowy o jej rozwoju bez nowoczesnych działań promocyjnych.

Bardzo istotną rolę w promowaniu turystyki i ochrony środowiska odgrywa szeroko rozumiana informacja. W gospodarce wolnorynkowej nie wystarczy samo posiadanie atrakcji turystycznych i pięknej przyrody, niezbędne są działania promocyjno - informacyjne w celu zapoznania $z$ ofertą jak największej liczby potencjalnych klientów.

Współczesna informacja turystyczna, jako podstawa działań promocyjnych, to zespół przemyślanych przedsięwzięć obejmujących, poza aktywną informacją o cechach ofensywnych, także poradnictwo, pomoc merytoryczną, a niekiedy także techniczno - organizacyjną dla organizacji i instytucji zainteresowanych promocją swoich ofert. Kampanie promocyjne mogą być realizowane przez pojedyńcze jednostki informacji turystycznej, które inspirują, uczestniczą w realizacji bądź samodzielnie realizują kampanie promocyjne. Głównym celem takiej działalności jest kreowanie nowego popytu, co znacznie ułatwia turystyczne ożywienie danego regionu.

3 R. SKAWIŃsKI, S. Woś, Ełk, Wydawnictwo ZF, Suwałki 1994. 
Działania informacyjno-promocyjne muszą być poprzedzone rozpoznaniem terenu działania. W tym celu przeprowadza się badania i analizy mające wskazać słabe i mocne punkty danego produktu czy usługi, w tym przypadku miasta Ełk i okolic.

Analiza SWOT to jedna z najpopularniejszych technik analitycznych, służąca do porządkowania informacji. Stosowana początkowo do analiz strategicznych przedsiębiorstw, od pewnego czasu jest także wykorzystywana do planowania rozwoju. Pozwala również zarysować pole gry strategicznej, określić zasoby i możliwości oraz ujawnić zakres koniecznych działań, pomaga wykryć złe i dobre strony naszej sytuacji.

Technika analityczna SWOT polega na posegregowaniu posiadanej informacji na dany temat na cztery grupy (cztery kategorie czynników strategicznych):

- S (Strengths) - mocne strony: wszystko to co stanowi atut, przewagę, zaletę analizowanego obiektu;

- W (Weaknesses) - słabe strony: wszystko to, co stanowi słabość, barierę, wadę analizowanego obiektu;

- $\mathbf{O}$ (Opportunities) - szanse: wszystko to co stwarza dla analizowanego obiektu szansę korzystnej zmiany;

- T (Threats) - zagrożenia: wszystko to co stwarza dla analizowanego obiektu niebezpieczeństwo zmiany niekorzystnej. ${ }^{4}$

Analiza SWOT oceniająca zarówno wewnętrzne jak i zewnętrzne czynniki, mogące mieć wpływ na powodzenie planu strategicznego stanowi użyteczną pomoc prowadzącą do dokonania analizy zasobów i otoczenia miasta oraz określenia problemów i priorytetów rozwojowych.

W celu uzyskania jasnej analizy mocne i słaby strony traktuje się jako czynniki wewnętrzne z punktu widzenia społeczności lokalnej, na które ma bezpośredni wpływ, a szanse i zagrożenia jako czynniki zewnętrzne wynikające $z$ niezależnych zmian $w$ otoczeniu. Wiedza wynikająca $z$ analizy SWOT jest szczególnie przydatna w procesach zarządzania, pozwala na skuteczne wychwycenie przewagi nad konkurencyjną i pozwala podjąć działania zmierzające do wykorzystania szans lub działań zmierzających do uniknięcia zagrożeń.

Analiza SWOT dla Ełku i okolic wykazała, że dla promocji regionu szczególnie przydatne są atuty powiązane z przyrodą lub jej ochroną. Są to m.in.:

- Dostęp do wód i lasów (liczne jeziora, rozległe lasy o wysokim stopniu czystości)

- Zasoby przyrodnicze (bogata fauna i flora, wystepowanie licznych gatunków chronionych)

- Obszar Zielonych Płuc Polski

4 A. LIMAŃSKI, K. ŚlıwińsKa, Marketing. Zasady funkcjonowania przedsiębiorstwa na rynku, Wyd. Difin, Warszawa 2002r., s. 358. 
Wplyw działalności promocyjno-informacyjnej administracji państwowej i samorządowej...

- Uporządkowana gospodarka wodno - ściekowa (kanalizacja, nie zanieczyszczanie wód gruntowych)

- Dobre utrzymanie zieleni miejskiej (parki, trawniki)

- Jakość środowiska naturalnego (brak ciężkiego przemysły i związanych z nim zanieczyszczeń)

- Centrum Edukacji Ekologicznej (działalność pro-ekologiczna)

- Porozumienie władz i mieszkańców w sprawie proekologicznego rozwoju miasta

- Położenie geograficzne

- Walory środowiskowe

Istnienie w/w atutów przyrodniczych daje wielkie szanse dla rozwoju społeczno-gospodarczego gminy, takie jak:

- Zgodność priorytetów regionalnych i władz miasta (rozwój Ełku i regionu nastawiony na turystykę)

- Racjonalne wykorzystanie terenów wokół miasta (zachowanie cennych przyrodniczo terenów, inwestycje na terenach na których nie będą zagrażały środ. naturalnemu)

- Współpraca samorządów

- Gospodarcze wykorzystanie walorów turystycznych Ełku i okolic (priorytet)

- Pozyskiwanie środków z Funduszy Strukturalnych (środki na infrastrukturę techniczną niezbędną dla zachowania walorów środowiska naturalnego jak np.oczyszczalnie, kanalizacja itp.)

- Upowszechnianie zdrowego trybu życia (np. profilaktyka antynikotynowa)

- Turystyka aktywna

- Budowa połączenia wodnego $z$ Wielkimi Jeziorami Mazurskimi (wielka szansa dla regionu, wykorzystując istniejące połączenia wodne można stworzyć jeden $\mathrm{z}$ największych $\mathrm{w}$ Europie szlaków turystyki wodnej na śródlądziu)

- Środki na likwidację bezrobocia (prace interwencyjne np.posezonowe sprzątanie lasów i jezior)

- Zmniejszenie bezrobocia - rozwój usług okołoturystycznych

- Stworzenie biura informacji turystycznej (na razie jest tylko punkt)

- Ełk jako centrum subregionu

- Funkcjonowanie w ramach obszaru „Zielonych Płuc Polski” (promocja miasta również $\mathrm{w}$ ramach działalności w strukturze ZPP)

Informacje uzyskane $\mathrm{z}$ tego typu badań są obecnie wykorzystywane przez instytucje podległe samorządom powołane do prowadzenia promocji miasta i regionu jako czystego ekologicznie, pełnego atrakcji turystyczno-przyrodniczych. Podstawowym zadaniem $w / w$ instytucji jest dotarcie do jak najwiekszej rzeszy odbiorców, którzy są potencjalnymi turystami. W tym celu wykorzystuje się środki masowego przekazu. Współpraca z prywatnymi przedsiębiorcami do- 
prowadziła do wydania albumów oraz folderów ukazujących piękno przyrody oraz mnogość wszelkich atrakcji turystycznych. Stworzono portal internetowy www.turystyka.elk.pl, który jest na bierząco uaktualniany. Potral zawiera wszelkie informacje niezbedne turyście, począwszy od wątków historycznych z regionu, przez prezentacje walorów turystyczno-przyrodniczych po informacje z życia miasta i okolic. W sezonie licznym organizowane są liczne imprezy plenerowe, np. przez Miejski Ośrodek Sportu i Rekreacji. Rzesze turystów poza znakomitą zabawą poznają na nich wszystkie atuty regionu np. kuchnię regionalną i wyroby rzemieślnicze. Dużą szansę na ukazanie walorów Ełku stanowi współpraca z telewizjami regionalnymi, ktora obecnie jest juz na poziomie zadowalajacym ale w przyszlości wymaga intensyfikacji. Wzorcem mogą być gminy leżące w obrębie pobliskiego Biebrzańskiego Parku Narodowego, które same inicjują powstawanie kolejnych programów poruszających problematykę przyrody i mieszkańców rejonu bagien biebrzańskich.

Działania promocyjne przy wykorzystaniu walorów przyrodniczo-turystycznych regionów mają jedną, bardzo ważną cechę - pomagają w uzyskaniu środków z Unii Europejskiej. Dofinansowania te w znacznym stopniu ułatwiaja dostosowanie infrastruktury miasta i okolic do wymagań europejskich. Działania takie poza wymiernymi korzyściami dla mieszkańców, jak np. Kanalizacja przynoszą ze sobą korzyści długofalowe w postaci zaprzestania degradacji środowiska naturalnego, które ma być przecież wizytówką regionu. Podobnie ma się sprawa z infrastrukturą drogową. Naprawa istniejących i budowa nowych szlaków komunikacyjnych ułatwi dostęp turystów do atrakcji turystyczno-przyrodniczych oraz zniweluje zagrożenie związane $z$ wypadkami komunikacyjnymi $z$ udziałem środków niebezpiecznych dla środowiska.

Dla działalności promocyjnej często powinno się wykorzystywać ogólnoświatowe akcje np. dzień ziemi. Warto miec na uwadze, że przekazana w ten sposób wiedza lub jej brak ma bezpośredni wpływ na postrzeganie przez spolecznośc lokalną dbałości o środowisko naturalne. Nie do zaakceptowania jest praktyka wielu gospodarzy, którzy chcą korzystać z dobrodziejstw jakie daje im natura, np.prowadząc gospodarstwa agroturystyczne a sami tą naturę niszczą np. wywożąć śmieci do lasu.

\section{Zakończenie}

Współczesna turystyka nie może istnieć bez promocji. Władze miasta Ełk i okolic upatrują szansę rozwoju gospodarczego w turystyce przy wykorzystaniu ogromnego potencjału jakim jest środowisko naturalne. W tej sytuacji oczywiste jest, że nie dbając o środowisko naturalne sami pozbawiamy się naszego głównego atutu w konkurencyjnej walce o turystę. 
Wplyw działalności promocyjno-informacyjnej administracji państwowej i samorzadowej...

Działalność promocyjno-informacyjna służy nie tylko indywidualnym turystom, ale również organizatorom wypoczynku grupowego, restauratorom, branży hotelarskiej jak również pojedynczym gospodarstwom agroturystycznym. Im wieksza jest świadomość społeczeństwa o stanie obecnym środowiska naturalnego w ich najblizszej okolicy, tym łatwiej jest zaplanować działania mające na celu jego ochronę, jak też organizację kampanii reklamowych regionu.

Bardzo szeroki wachlarz dostępnych narzędzi w dziedzinie gromadzenia, przetwarzania i udostępniania informacji może być w pełni wykorzystywany w turystyce z pełnym uwzględnieniem grup odbiorców, rynków czy poszczególnych produktów. Takimi odbiorcami są m.in.: samorząd lokalny i gospodarczy, przewoźnicy, piloci, przewodnicy, twórcy produktów turystycznych, animatorzy wydarzeń kulturalnych, firmy poszukujące usług turystycznych, turyści indywidualni oraz grupy zorganizowane, lokalne społeczności, media, szkoły turystyczne.

Region Polski Północno-Wschodniej jest wolny od ciężkiego przemysłu. Bogactwo fauny i flory oraz wyjątkowe walory krajobrazowe przez wiele organizacji miedzynarodowych zastały uznane za przyrodnicze dziedzictwo Europy. Celem mieszkańców tych regionów powinno byc zachowanie i umacnianie tego wizerunku. Wiele jest przykładów państwa i regionów, które pogodziły rozwój gospodarczy z dbalością o środowisko naturalne. Warto dołączyć do tego elitarnego grona.

\section{Bibliografia}

LIMAŃsKı A., ŚLIWIŃsKa K., Marketing. Zasady funkcjonowania przedsiębiorstwa na rynku, Wyd. Difin, Warszawa 2002.

Skawıśski R., Woś S., Ełk, Wydawnictwo ZF, Suwałki 1994.

www.biblioteka.elk.pl

www.smswit.elk.com.pl/kultura.htm

www.turystyka.elk.pl 